\title{
ІСТОРИКО-РЕТРОСПЕКТИВНИЙ АНАЛІЗ СТАНОВЛЕННЯ СЕСТРИНСЬКОЇ СПРАВИ Й МЕДСЕСТРИНСЬКОЇ ОСВІТИ
}

\author{
А. О. Бурименко \\ ДВНЗ «Тернопільський державний медичний університет \\ імені І. Я. Горбачевського МОЗ Украӥни»
}

Уточнено визначення сестринської справи. Визначено етапи становлення сестринської справи й медсестринської освіти. Розглянуто сутність кожного із зазначених періодів.

\section{HISTORICAL AND RETROSPECTIVE ANALYSIS OF THE DEVELOPMENT OF NURSING CARE AND NURSING EDUCATION}

\section{A. O. Burymenko}

\section{Horbachevsky Ternopil State Medical University}

The definition of the nursing care is specified. The stages of the development of nursing care and nursing education are determined. The nature of each of these periods is considered.

Вступ. Сестринська справа (медсестринство) за визначенням ВООЗ - це складова частина системи охорони здоров'я, яка спрямована на вирішення проблем індивідуального та громадського здоров'я населення в мінливих умовах навколишнього середовища. Потреба в медсестринському процесі універсальна. Вона передбачає надання кваліфікованого догляду за пацієнтом, опіку над ним у широкому сенсі (побутовому, соціальному, духовному, національному, расовому, з точки зору традицій тощо); відіграє важливу роль в реалізації соціальних, психологічних, духовних заходів, спрямованих на поліпшення якості здоров'я та життя пацієнтів. Зростання ролі медичних сестер у діагностично-лікувальному процесі, випереджувально-профілактичних, медичних й екологічних заходах свідчить про актуальність реформ у медсестринській галузі як складовій системи охорони здоров'я та у сфері вищої медичної освіти. Сестринська справа із залежного підрозділу медицини нині розвинулась у самостійну науку, яка має свою філософію, теорію і стандарти. Це передбачає розробку нових підходів до підготовки висококваліфікованих фахівців сестринської справи.

Основна частина. Освіта медичних сестер в Україні як система навчання і виховання кадрів різних освітньо-кваліфікаційних рівнів має свою історію й

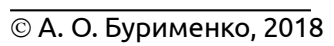

тісно пов'язана зі світовою системою медсестринської освіти. Зважаючи на це, ми ставили за мету вирізнити особливості періодів становлення сестринської справи і медсестринської освіти.

Найбільш ґрунтовний системний аналіз становлення та розвитку сестринської справи висвітлено у працях М. Б. Шегедин $[4,5]$. Науковець зуміла охарактеризувати не тільки шляхи становлення світової медицини, але й виокремити роль і значення медсестринства як її складової. На думку автора, загальновизнаною $€$ періодизація історії медсестринства, яка співпадає із загальноісторичною періодизацією розвитку людства та медицини. Приєднуючись до цієї думки, вважаємо, що процес становлення медсестринства та підготовки медичних сестер як соціального замовлення потрібно умовно поділити на такі періоди:

- виникнення елементів стихійного (досестринського) догляду;

- зародження ранньої сестринської справи;

- створення перших закладів із підготовки працівниць із догляду за хворими;

- розробки наукових засад організації сестринської справи й освіти;

- упровадження ступеневої медсестринської освіти. Розкриємо сутність зазначених періодів.

Період виникнення елементів стихійного (досестринського) догляду (з найдавнішихчасів до V ст. н. е.). 
3 появою у стародавньому суспільстві необхідності у збереженні індивідуального та колективного здоров'я стихійно виникли перші елементи догляду за хворими. Ці елементи мали переважно характер ритуальних дій і поступово доповнювалися емпіричними медичними знаннями. Дані антропології та археології переконливо свідчать, що потреба в допомозі під час хвороб і травм виникла ще в умовах первісного суспільства. Спочатку вона не відокремлювалась від власної життєдіяльності людини, її відчуттів і переживань, інстинкту самозбереження. Але поступово, з формуванням людських колективів, допомога при хворобах і травмах стала засобом збереження життя, здоров'я і працездатності.

Період зародження ранньої сестринської справи (V-XII ст. н. е.) характеризується виникненням усвідомлених заходів, спрямованих на систематизацію накопичених знань, умінь, навичок із догляду й опіки за хворими. Це дало можливість спрямувати допомогу при хворобах і травмаху професійне русло. Головним стимулом розвитку ранньої сестринської справи стало виникнення та поширення християнства. У народів, які прийняли християнство, цьому сприяло визнання основних принципів моралі та милосердя, закладених у Біблії. Перші общини жінок для служіння справі милосердя і догляду за хворими було створено в XI ст. у багатьох країнах Західної Європи. Значний внесок у розвиток сестринської справи зробили світські ордени, зокрема Госпітальне братство Святого Антонія (Франція, Іспанія, Італія,) Святого Іоанна (Єрусалим) [3]. Сестри, які входили до орденів, давали обітницю проводити весь свій час, доглядаючи за хворими [3].

Період створення перших закладів з підготовки працівниць із догляду за хворими (XIII-XVIII ст.). Масові епідемії, стихійні лиха, численні війни були важливими соціальними чинниками, які сприяли розвитку сестринської справи. Саме в цей період нагальною стала потреба в підготовці працівників із догляду за хворими та створенні відповідних навчальних закладів. В епоху Відродження на зміну образу духовної сестри - «служниці Божої» поступово приходить образ сестри милосердя, сестри-служниці [5].

За часів середньовіччя на території сучасної України не було жодних медичних навчальних закладів, а навчання мистецтву лікувати та доглядати за хворими здійснювалося шляхом передачі знань від батьків дітям або на зразок ремісного учнівства при монастирях. Найважливішим було втішати, виявляти співчуття та безкорисливо виконувати роботу з догляду. Такий образ медичної сестри, яка жертвує собою заради хворих, вихованої на беззаперечній покірності, не зацікавленої в утворенні власної сім'і, глибоко вкоренився в суспільній свідомості протягом багатьох поколінь.

Період розробки наукових засад організації сестринської справи й освіти (поч. XIX ст. - кін. XIX ст.) характеризується посиленням уваги до сестринської справи та освіти шляхом відродження протестантською церквою общини «диякониць» (1836 р., Кайзерверст на Рейні, Німеччина) [3]. Модель підготовки персоналу в Кайзерверсті є прикладом для медсестринської освіти в усьому світі.

Найвизначнішою подією цього періоду стало відкриття Флоренс Найтінгейл (1820-1910 рр.) першої в світі школи з підготовки сестер милосердя (Лондон, 1860 р.). Флоренс Найтінгейл дала перше визначення сестринській справі і вважала, що сестринська справа як професія відрізняється від лікарської діяльності й потребує спеціальних, відмінних від лікарських, знань і трактувала ї̈ як «дію з використання навколишнього середовища для сприяння видужанню пацієнта» [1]. Вона писала: що «сестра повинна мати потрійну кваліфікацію: душевну - для розуміння пацієнтів, наукову - для розуміння хвороби, технічну - для догляду за пацієнтом» [1]. На її думку, сестринська справа повинна бути незалежною, самостійною та почесною професією, суміжною з медичною, не підпорядкованою їй.

За ініціативою М. Пирогова вперше в історії військово-польової хірургії було здійснено «спеціалізацію» серед медичних сестер, де враховувався рівень їх знань і здібностей. Таким чином, практичний досвід роботи медсестер у воєнний час довів необхідність розширення їх функцій, порівняно з сиділками, та підвищення якості надання ними медичної допомоги. Було доведено, що сестри повинні вміти створювати умови для лікування і попередження хвороб; знати ознаки хвороб, ліки, їх дію та ускладнення; вміти вести документацію, в якій фіксуються зміни стану хворих і поранених, зауваження і пропозиції з догляду за ними. Для реалізації цих та інших функцій було вирішено створити і розвивати цілу систему підготовки медсестринського персоналу не тільки на випадок війни, але й для мирного часу.

Систематична підготовка медичних сестер в Україні розпочалася з другої половини XIX ст. і здійснювалась потужними на той час медичними закладами (Олександрівська лікарня, Київський військовий шпиталь, Кирилівська лікарня та ін.). У них діяли курси з підготовки сестер милосердя Червоного Хреста. 
Період упровадження ступеневої медсестринської освіти (поч. XX ст. - до сьогодні). Характерною особливістю цього періоду $є$ розробка наукової концепції ступеневої неперервної вищої медсестринської освіти. Запровадження ступеневої підготовки медичних сестер у світі (початок XX ст.) зумовлювалося різними чинниками, передусім утвердженням суспільних демократичних цінностей, науково-технічним прогресом, трансформаціями в суспільстві, розвитком медсестринської освіти, в напрямі трансформації вимог до особистості медичної сестри, ії підготовки й професійної діяльності.

Центром розвитку ступеневої сестринської освіти стають Сполучені Штати Америки. Американська модель ступеневої вищої медсестринської освіти передбачала: 1) підготовку медичних сестер-адміністраторів для медсестринських служб; 2) запровадження базової та післядипломної університетської медсестринської освіти; 3) підготовку магістрів із медсестринства (1920 р.). Зазначимо, що перші магістерські програми були націлені на підготовку менеджерів та викладачів сестринської справи.

У середині XX ст. розпочато розробку науково-теоретичної бази фахівців із вищою медсестринською освітою, реорганізацію та акредитацію вищих медсестринських навчальних закладів, запровадження бакалаврату для професійних медичних сестер.

\section{СПИСОК ЛІТЕРАТУРИ}

1. Грибанов Э. Д. Женщина со светильником : (К 175-летию со дня рождения Флоренс Найтингейл) / Э. Д. Грибанов // Медицинская помощь. - 1995. - № 3. - С. 50-56.

2. Павлов Ю. И. Теория сестринского дела / Ю. И. Павлов, А. А. Холопов. - Челябинск : ГКПТ, 2006. - С. 5-20.

3. Пасєчко Н. В. Основи сестринської справи : курс лекцій / Н. В. Пасєчко. - Тернопіль : Укрмедкнига, 1999. 496 c.
Американський підхід до концепції медсестринської діяльності й медсестринської освіти домінував у світі до кінця Другої світової війни.

У Європі (середина XX ст.) створено загальні засади базової підготовки медичних сестер. Між Данією, Францією, ФРН, Грецією та Великою Британією підписано «Європейську угоду про медсестринську освіту» (1968 p.) [3].

У 1971 р. було створено Постійний комітет медичних сестер при Європейському економічному співробітництві. Прийняті комітетом директиви визначили єдині підходи до підготовки й діяльності медсестринського персоналу в $є$ вропі. Одна з директив засвідчила взаємне визнання дипломів і заходи, які забезпечували 6 право вільного вибору місця проживання та праці медичних сестер. У 1989 р. відповідно до міжнародної номенклатури спеціальність «Медична сестра» була перейменована в «Сестринську справу». Було введено новий навчальний план із цієї спеціальності, в якому вперше була представлена дисципліна «Основи сестринської справи» [5].

Висновки. Для розвитку сестринської справи і використання сучасних наукових підходів до організації освіти фахівців медсестринства необхідно враховувати історичний і світовий досвід професійної підготовки медичних сестер.

4. Шегедин М. Б. Медико-соціальні основи реформування медсестринських кадрових ресурсів системи охорони здоров'я : дис. ... доктора мед. наук : 14.02.03 / М. Б. Шегедин. - К., 2001. - 332 с.

5. Шегедин М. Б. Медсестринство в Україні : навч. посіб. / М. Б. Шегедин. - Тернопіль : Укрмедкнига, 2003. - 280 с.

Отримано 25.01.18 